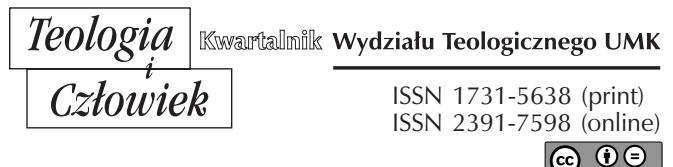

44(2018)4, ss. 79-95

KS. PAWEK SZCZEPANIAK

UNIWERSYTET GREGORIAŃSKI W RZYMIE

PAWELSZCZEPANIAK@VP.PL

ORCID 0000-0003-2908-7720

\title{
ZADANIA I CELE ARTYSTY I SZTUKI WSPÓŁCZESNEJ WE WSPÓLNOCIE KOŚCIOŁA, WEDŁUG MYŚLI KARDYNAŁA G. B. MONTINIEGO - ARCYBISKUPA MEDIOLANU (1954-1963)
}

DOI: http://dx.doi.org/10.12775/TiCz.2018.040

Streszczenie. Artykuł jest próbą wypełnienia luki w literaturze polskiej na temat nauczania G. B. Montiniego na temat sztuki i roli artysty we wspólnocie Kościoła. Z wielu przemówień i homilii biskupa Mediolanu z lat 1954-1963, zostały wybrane te, które mogłyby odzwierciedlić ideę jego niezmordowanego poszukiwania dialogu między duchowością chrześcijańską a twórczością artystyczną po II wojnie światowej. Misje Święte podjęte na początku episkopatu dla diecezji mediolańskiej, budowa nowych kościołów, wpływ liturgii na kształtowanie wnętrza świątyni, to tylko niektóre tematy poruszone przez Montiniego, które pozwoliły na lepsze zrozumienie roli twórców w dziele ewangelizacji.

Słowa kluczowe: sztuka sakralna; Montini; Mediolan; artysta; sztuka współczesna.

\footnotetext{
Abstract. Duties and Goals of the Artist and Contemporary Art in the Community of the Church, According to Cardinal G.B. Montini - Archbishop of Milan (1954-1963). The article tries to fill the gap in Polish literature on the teaching of G. B. Montini on the art and the role of the artist in the community of the Church. From many speeches and homilies of the Bishop of Milan covering the years 1954-1963, there have been selected those that could reflect the idea of his tireless search for a dialogue between Christian spirituality and artistic creativity after World War II The Holy Missions undertaken for the diocese of Milan at the beginning of the episcopate, the construc-
} 
tion of new churches, the influence of the liturgy on the interior of the temple, are just some of the topics raised by Montini, which allowed a better understanding of the role of creators in the work of evangelization.

Key words: Sacral art; Montini; Milan; artist; contemporary art.

Trudno sobie wyobrazić chrześcijaństwo pozbawione sztuki. W kontekście pastoralno-liturgicznym poprzez kolor i formę sztuka pozwala na przybliżanie prawd wiary. W historii, artystyczny geniusz starał się przełożyć dogmat wiary na zrozumiały dla wszystkich język. Kościól, będąc jednym z głównych mecenasów sztuki i kultury, poprzez jej wytwory trafiał do wiernych z przesłaniem Słowa Bożego - głównego źródła artystycznego natchnienia. Od XVIII w., pod wpływem wydarzeń politycznych, rodzących się nowych idei filozoficznych w tym Oświecenia, artyści będący częścią sceny zmieniającego się społeczeństwa obierają kierunki odmienne od tych proponowanych przez Kościół. Wyraźnie zaczyna się odczuwać rozdźwięk między inspiracją wypływającą z wiary a twórczością artystyczną, która powoli okręca się w narcystycznym uścisku samej siebie ${ }^{1}$. Powiększa się on w miarę upływu czasu a sztuka związana $\mathrm{z}$ sacrum zatraca $\mathrm{w}$ powielaniu utartych schematów, bez większego wysiłku poszukiwania nowych i bardziej adekwatnych rozwiązań. Lata dwudzieste XX w. ożywiają dyskusję nad dostosowaniem się sztuki sakralnej do nowych tendencji modernistycznych, zwłaszcza w architekturze. Dyskusja odbywa się wewnątrz Kościoła między tradycjonalistami przywiązanymi do rozwiązań proponowanych przez sobór trydencki i modernistami, którzy dopuszczają do głosu współczesne idee proponowane przez kierunki rodzące się na ich oczach. Debata nad tym, jaka powinna być sztuka sakralna pojawia się ponownie po II wojnie światowej, kiedy to wspólnota Kościoła staje przed niełatwym zadanie odbudowy ze zgliszczy dziedzictwa sakralnego ${ }^{2}$.

1 Por. A. Dall'Asta, Arte cristiana e cultura contemporanea. Tra declino e speranza di riscatto, „La Civiltà Cattolica”, 4011-4012 (2017) 3, s. 305-306.

2 Por. G. Pappalardo, Lo spazio sacro del Novecento: architetture religiose delle città e dei borghi di fondazione nell'Italia meridionale, „Bollettino del centro di studio per la storia dell'architettura”. 42-43-44 (2005-2007), s. 142. 
Autor w niniejszym artykule pragnie przybliżyć myśl G. B. Montiniego na temat sztuki sakralnej, podczas jego bogatej posługi w diecezji ambrozjańskiej. Aby sprostać temu, niełatwemu zadaniu, autor posłuży się zbiorem homilii i przemówień G. B. Montiniego oraz zarysuje problem duszpasterski budowy nowych kościołów na przedmieściach Mediolanu lat pięćdziesiątych i sześćdziesiątych. Owa panorama pozwoli na lepsze ujęcie i zrozumienie wysiłku jaki podjął Paweł VI w budowaniu mostów między sztuką współczesną a Kościołem.

\section{ENCYKLIKA „MEDIATOR DEl" PAPIEŻA PIUSA XIl POCZĄTKIEM TRUDNEJ DYSKUSJI}

Pierwszym istotnym sygnałem XX wieku i próbą zmierzenia się z problemem sztuki sakralnej była encyklika papieża Piusa XII z 1947 r. Mediator $D e i^{3}$. Papież podkreśla w niej wagę liturgii, która jest fundamentem i drogowskazem w dyskusji nad sztuką sakralną. Encyklika zwraca uwagę na potrzebę dostrzeżenia nowych rozwiązań, ujęć i form proponowanych przez współczesny świat. Nawołuje do pozostawienia miejsca dla sztuki współczesnej, tak aby mogła w pełni służyć dobru kultu. Jednocześnie przestrzega przed zwykłym powtarzaniem schematów oraz stosowaniem niezrozumiałych symboli, a co więcej niezrozumiałego i subiektywnego języka ekspresji. Choć więc encyklika dopuszcza nowe tendencje, to sprzeciwia się i wręcz potępia nowe formy artystyczne, które są sprzeczne z duchem chrześcijaństwa. Sztuka, w myśli Piusa XII, ma służyć kultowi. Kierować wiernych w stronę Boga. Encyklika Mediator Dei jest bez wątpienia punktem wyjścia do dalszych refleksji na temat stanu sztuki sakralnej oraz miejsca artysty w Kościele. Papież nawołuje do otoczenia specjalną opieką duszpasterską artystów, gdyż to właśnie im zostaje powierzona misja odbudowy po zniszczeniach wojennych dóbr kultury ${ }^{4}$.

3 Por. E. De Caro, Lestetica e il progetto di nuova evangelizzazione degli artisti, «Itinera» 11 (2016), s. 206.

${ }^{4}$ Por. Pius XII, Mediator Dei, AAS 39 (1947), s. 521-595. 


\section{POTRZEBA MISJI ŚWIĘTYCH W MEDIOLANIE}

W obliczu tak zarysowanej problematyki sztuki, intelektualista Giovanni Battista Montini zostaje nominowany biskupem Mediolanu. W styczniu 1955 r. staje na czele jednej z największych diecezji świata, gdzie stawia czoło kompleksowi problemów. Sekularyzacja Mediolanu lat pięćdziesiątych postępuje bardzo szybko. Religijność przechodzi kryzys. Według danych Akcji Katolickiej z 1950 r. między 14\% a 35\% mediolańczyków uczęszcza na niedzielne msze święte. Co więcej, odczuwa się oficjalny klimat między Kościołem a społeczeństwem a sekularyzacja postępuje szybciej niż w pozostałej części Włoch ${ }^{5}$. Nowy arcybiskup Montini, mając przed sobą panoramę problemu, kieruje uwagę na rozwój pastoralny parafii. W zaledwie dwa lata po objęciu Mediolanu decyduje się na nowatorski ruch, jakim jest zorganizowanie Misji Świętych dla diecezji ambrozjańskiej (5-24 listopada 1957). Ruch nowatorski, gdyż misje mają opierać się na naukach religijno-duchowych, a nie jak to działo się do tej pory - na moralności. Poza tym Montini zachęca do współpracy sam laikat, a nie jedynie do biernego udziału w dziele ewangelizacji. W końcu Misje są skierowane do ludzi pracy, a miejscem ich przeprowadzenia mają być parafie, jako jednostki będące najbliżej środowiska robotniczego parafie, które znają problemy współczesnego człowieka ${ }^{6}$. Rozrastający się Mediolan ma więc potrzebę organizacji pracy pastoralnej opartej na parafiach, których brakuje w szczególności w nowych dzielnicach. Z tego też względu, Montini podczas swego ośmioletniego episkopatu wznosi 115 nowych kościołów, w tym $41 \mathrm{w}$ samym Mediolanie i $74 \mathrm{w}$ dzielnicach poza miastem. Parafie stanowią zaplecze ewangelizacyjne oraz dają możliwość do zaprezentowania nowych rozwiązań architektury sakralnej ${ }^{7}$ Parafia ma być nie tylko miejscem kultu, ale prowadzić działalność charytatywną, być miejscem spotkań, aktywności religijnej, moralnej i kulturalnej

${ }^{5}$ Por. G. Adornato, Giovanni Battista Montini. Religione e lavoro nella Milano degli anni '50, Brescia 1988, s. 23.

${ }^{6}$ Por. G. Adornato, Giovanni Battista Montini, s. 107-109.

7 Por. F. Salamone, Perenne rivelazione dellarte cristiana. Per una teologia dellarte in Paolo VI, Palermo 2013, s. 50. 
dla wszystkich grup społecznych i wiekowych ${ }^{8}$. Zastosowanie nowości technicznych, w tym żelbetonu pozwala na tworzenie planów praktycznie niczym nieograniczonych.

\section{KOMITET DS. NOWYCH KOŚClOŁÓW}

Mediolan nie po raz pierwszy spotyka się z problemem budowania nowych świątyń. Poprzednik Montiniego, kardynał Ildefonso Schuster (1880-1954) był pierwszym przewodniczącym Papieskiej Komisji do spraw Sztuki Sakralnej w Rzymie. Już w 1929 r. aktywował on komisję diecezjalną ds. sztuki sakralnej, powołując do niej architektów zaangażowanych w obowiązujące nurty początku dwudziestego wieku. W $1937 \mathrm{r}$. powołał Komitet ds. Nowych Kościołów, który miał sprostać potrzebie budowania świątyń w dzielnicach Mediolanu, które wskutek szybkiego rozwoju były pozbawione miejsca kultu. Po okresie wojennym, w którym działalność Komitetu została zawieszona, w 1950 r. na nowo podejmuje się trud odbudowy i budowy ex nuovo budynków parafialnych w dzielnicach podmiejskich. Kluczową rolę w rozbudowie zajmuje inżynier Enrico Mattei, który z kolei włącza do Komisji nowych członków będących znamienitymi specjalistami w swoich dziedzinach ${ }^{9}$. Innym bardzo ważnym współpracownikiem Montiniego w pracach nad konstrukcją nowych kościołów, jest ks. Pasquale Macchi, który wraz z Dandolo Bellini w 1955 r. daje początek Kolekcji Współczesnej Sztuki Sakralnej (Collezione di arte religiosa moderna) przy Villa Clerici w Nigarda. Jest ona prototypem kolekcji, które narodzą się w Brescii i w Bolonii dając miejsce współczesnej duchowości wyrażonej w sztuce, będącej córką swojego czasu. Sztuki, która łączy wielowiekową duchowość chrześcijaństwa $\mathrm{z}$ trendami współczesnej filozofii i estetyki ${ }^{10}$. Obejmując ambrozjańską katedrę w słowie skierowanym podczas Bożego Narodzenia 1955 r., ar-

8 Por. C. De Carli, Le nuove chiese, w: Montini. Arcivescoco di Milano, L. Bressan, A. Maffeis (red.), Brescia 2016, s. 298-299.

9 Por. M. A. Crippa, Lesperimento pastorale del card. Giovanni Montini nella diocesi ambrosiana, w: La diocesi di Milano e le nuove chiese 1954-2014. Atti del Convegno, 4 novembre 2014, L. Lazzaroni (red.), Milano 2016, s. 64-65.

${ }^{10}$ Por. F. Salamone, Perenne rivelazione, s. 52. 
cybiskup Montini zwraca uwagę na konieczność budowy miejsc kultu przede wszystkim w nowych i rozwijających się dzielnicach. Stwierdza, iż miasta mające $\mathrm{w}$ centrum pomniki historii sztuki i kultury, nie mogą być okrążone przez materializm i pogaństwo. Wzywa do uczestnictwa w dziele budowy organy władzy, właścicieli, przedsiębiorców, proboszczów, osoby życia konsekrowanego i świeckich ${ }^{11}$. Apel znajduje głębokie zrozumienie i odzew. Napływają ofiary od instytucji i osób prywatnych. Sam Montini ofiaruje na rzecz budowy nowych kościołów złoty krzyż pektoralny wysadzany kamieniami oraz pastorał $\mathrm{z}$ diamentem, dary otrzymane $\mathrm{z}$ okazji ingresu do diecezji ${ }^{12}$.

\section{ARTYSTA W MYŚLI MONTINIEGO}

Działalność Montiniego nie kończy się jednak jedynie na jednorazowych konkretnych gestach, skierowanych w stronę konstrukcji nowych kościołów mających być centrami duchowości chrześcijańskiej na peryferiach zsekularyzowanego Mediolanu. Zachęcając do czynnego uczestnictwa w wielkim projekcie, jakim były Misje, na zakończenie mszy świętej dla artystów celebrowanej przez mons. Ernesta Pisoniego, arcybiskup zwraca się do świata sztuki, podkreślając, że Kościół wprowadza do kultu, który sam z siebie jest duchowy, rzeczy materialne. Jednocześnie podkreśla, że to właśnie środowisko artystyczne jest tym, które je produkuje. Kontynuuje:

więc nie mówcie [artyści], że Kościół was nie rozumie, że was nie wzywa i nie zaprasza. Poczujcie wezwanie Kościoła. On mówi do was: «przybądźcie aby mi pomóc, ponieważ ja mam skarb, który pragnę ofiarować ludowi; wy dajcie formę tym wzniosłym ideom religii; ja wywyższę waszą sztukę do Kapłaństwa, które niech będzie pośrednikiem między Bogiem a ludźmi». Kościół potrzebuje magisterium i misterium artystów ${ }^{13}$.

${ }^{11}$ Por. G.B. Montini, E' venuta l'ora di un'arte cattolica nuova, w: Discorsi e scritti milanesi (1954-1963), X. Toscani (red.), vol. I, Brescia-Roma 1997, s. 563-565.

${ }^{12}$ Por. C. De Carli, Le nuove chiese, s. 298-300.

13 „[...] Quindi non dite che la Chiesa non vi comprende, che non vi chiama e non vi invita. Sentite la chiamata che la Chiesa vi fa. Essa dice: «Venite ad aiutarmi, perchè io ho un tesoro da consegnare agli uomini; date forma a questi concetti cublimi 
$\mathrm{Na}$ zakończenie podkreśla potrzebę duchowości, bliskości Boga do wyrażania tego c o niewidzialne $\mathrm{w}$ tym co widzialne. „Jeśli artysta jest oświecony przez Boga, będzie zdolny do wyrażenia Boga. Aby to zaistniało potrzebujecie być uczniami pierwej niż mistrzami; aby wyrazić, trzeba najpierw pojąć"14.

\section{ROLA LITURGII W TWORZENIU SZTUKI SAKRALNEJ}

Po sukcesie pastoralnym, jakim były Misje Święte, 7 lutego 1958 r. arcybiskup Montini, kieruje do wiernych List Duszpasterski na Wielki Post. W właściwym dla siebie stylu pyta o trwałość owoców Misji, tak aby nie pozostały jedynie wspomnienia po tak istotnym wydarzeniu w dziejach diecezji ambrozjańskiej. W cytowanym Liście Duszpasterskim, Montini koncentruje się na liturgii, jako centrum życia duchowego dla całego Kościoła, w tym także sztuki współczesnej, która ma służyć odnowionej liturgii, ma pomagać w jej lepszym zrozumieniu i przeżywaniu.

Jest [liturgia] jak centralna arteria, do której prowadzą pozostałe strumienie modlitwy prywatnej i ludowej i z której wywodzą się inne dla prywatnego życia duchowego; jest ona tą za którą wszyscy, pasterze i wierni, są zobowiązani podążać, nie z czystego obowiązku ale, aby czerpać z niej wewnętrzny, niezbędny pokarm. [...] Liturgia pojawia się dziś jako centralna kwestia życia pastoralnego ${ }^{15}$.

della Religione; io ho da elevare la vostra arte a Sacerdozio, che sia mediatore tra Dio e gli uomini». La Chiesa ha bisogno del magistero e del ministero degli artisti”. G.M. Montini, Il miracolo delle vetrate, w: Discorsi e scritti milanesi (1954-1963), X. Toscani (red.), vol. I, Brescia-Roma 1997, s. 1701.

${ }^{14}$, „.... $]$ Se l'artista è illumianto da Dio, sarà capace di esprimere Dio. E perchè questo avvenga avete bisogno di essere discepoli, prima che maestri; per poter esprimere, bisogna prima imprimere". G.M. Montini, Il miracolo, s. 1701.

15 „E' questa come l'arteria centrale, a cui conducono altri ruscelli di preghiera privata o popolare, e da cui altri derivano per la vita spirituale personale; ed èquella che tutti, pastori e fedeli, sono obbligati a seguire, non per puro dovere di esteriore osservanza, ma per averne interiore indispensabile alimento. [...] La liturgia si pone oggi come problema centrale di vita pastorale". G.M. Montini, L'educazione liturgica, Lettera pastorale allarcidiocesi per la Quaresima, w: Discorsi e scritti milanesi (1954-1963), X. Toscani (red.), vol. II, Brescia-Roma 1997, s. 1932-1933. 
Liturgia w myśli Montiniego jest nie tylko zbiorem gestów i słów, ale przede wszystkim drogą formacyjną dla wszystkich, włączając ludzi kultury $^{16}$. Edukacja liturgiczna oraz zainteresowanie liturgią przez Montiniego sięga jego czasów młodzieńczych, kiedy to w 1922 r. uczestniczył w organizowanym przez o. Bevilaqua, tygodniu liturgicznym. W tekście wyraźnie są cytowani Guardini, Jungmann, oraz encyklika Mediator Dei, która stanowi fundament w myśli duszpasterskiej Montiniego ${ }^{17}$. W dalszej części Listu, arcybiskup nawołuje do odnowy życia religijnego zwłaszcza w obliczu, jak sam podkreśla „dekadencji duchowej naszych czasów”"18. Odnowa o której mowa zakłada nowość.

Odrodzenie musi zakładać dar życia, to znaczy zrozumienie i uczestnictwo, piękno w kulcie liturgicznym [...]. Liturgia nie jest jedynie akcją kapłanów, ale również wiernych w ich własnych formach uczestnictwa. Nie jest jedynie dla kapłanów, jest także dla wiernych ${ }^{19}$.

W tym aspekcie, Montini wybiega do przyszłych zaleceń Soboru Watykańskiego II. Mówiąc o bardziej świadomym uczestnictwie wiernych, Montini zwraca uwagę na aspekt architektoniczny świątyni.

To wszystko domaga się zabiegów, które wydają się jedynie łatwymi sprawami organizacyjnymi: przede wszystkim dobrze przemyślaną godziną, odpowiadająca potrzebom wiernych, następnie światłem, ławkami, rozmieszczeniem wiernych, centralnym usytuowaniem ołtarza ${ }^{20}$.

${ }_{16}$ Por. G.M. Montini, Leducazione liturgica, s. 1936.

17 Por. G.L. Potestà, L'episcopato di G. M. Montini a Milano (1955-1963), w: Chiese italiane e Concilio. Esperienze pastorali nella chiesa italiana tra Pio XII e Paolo VI, G. Alberigo (red.), Genova 1988, s. 107.

18 Por. G.M. Montini, Leducazione liturgica, s. 1938.

19 „La rinascita deve consistere nel dare vita, cioè comprensione e partecipazione, bellezza, al culto liturgico, [...]. La liturgia non è azione dei soli Sacerdoti, ma anche dei fedeli, nelle forme di partecipazione loro proprie. Non è solo per i Sacerdoti, è anche per i fedeli». G.M. Montini, Leducazione liturgica, s. 1940.

20 „Tutto questo reclama premure, che sembrano di semplice valore organizzativo: l'orario, specialmente, bene studiato secondo l'opportunità dei fedeli, fisso e sobrio; poi la luce, i banchi, la disposizione locale dei fedeli, la centralità dell'altare [...]". G.M. Montini, L'educazione liturgica, s. 1940-1941. 
Zgromadzenie liturgiczne jest nie tylko biernym odbiorcą gestów, słów i wnętrza świątyni. Wierni są zachęcani do lepszego, bardziej świadomego odbioru tego, co ich otacza. Pomocą w tym ma być dobrze zaprojektowana architektura wnętrza w której istotną rolę odgrywa światło. W 28. punkcie Listu, Montini zwraca uwagę na pozycję i oświetlenie ołtarza, który ma stanowić centrum świątyni.

Oto zaszczytność ołtarza, który musi być widocznym i centralnym elementem. Nawet w największych świątyniach chrześcijańskich obecnie widzi się często ołtarze prowizoryczne, ale widoczne, które zastępują monumentalne ołtarze, pogrzebane w odległych i ciemnych absydach. Musi być on oświetlony w sposób, w który przyciągnie na siebie wzrok wszystkich; bez teatralności, ale z maksymalnym dostojeństwem. Przyozdobiony pięknem, wstrzemięźliwością i elegancją elementów, które stanowią jego wyposażenie, $\mathrm{z}$ różnorodnością kolorów stosownie do momentów liturgicznych ${ }^{21}$.

Atmosferę liturgii podkreśla światło, które ma odkryć przed uczestnikami piękno ukryte w ciemnych wnętrzach świątyń. Tak więc, problem odpowiedniego oświetlenia odnosi się również do całości kościoła.

Widoczność musi się odnosić nie tylko do ołtarza, ale całej powierzchni sakralnej, która została skonstruowana w swej integralności i ze swymi szczegółami jako strona stale pouczająca i kształtująca. Ma miejsce niekiedy fakt, iż większa część wiernych, którzy uczęszczają od lat do tej samej świątyni nigdy nie zatrzymała wzroku na jej jednolitej strukturze i na mnóstwie jej historycznego i artystycznego piękna. W związku z tym aby oko wiernego mogło odkryć chwałę Boga w Jego Kościele, każdy szczegół świątyni musi być utrzymany w porządku i ukazywany dla pokrzepienia duchowego ${ }^{22}$.

${ }^{21}$ „Ecco la preminenza dell'altare, che dev'essere centrale e visibile. Anche nei massimi templi della cristianitàora si vedono spesso altari provvisori, ma visibili, che sostituiscono altari monumentali, ma sepolti in absidi lontane ed oscure. Dev'essere illuminato, in modo da attrarre sopra di sè lo sguardo di tutti; senza teatralità, ma con massimo decoro, e ornato con bellezza, sobria ed elegante, di suppellettili, con varietà di colori secondo i momenti liturgici". G.M. Montini, L’educazione liturgica, s. 1943,

${ }^{22}$ „E la visibilità deve realizzarsi non solo per l'altare, ma per tutta l'aula sacra, che è stata costruita, nella sua unità e nei suoi particolari, quale pagina perennemente istruttiva ed edificante. Avviene talora che la maggior parte dei fedeli frequenta da anni 
Znaczenie światła $\mathrm{w}$ świątyni zostanie zrealizowane $\mathrm{w}$ nowopowstających kościołach na peryferiach Mediolanu. Przykładem mogą być kościoły Madonna dei Poveri w Baggio, zaprojektowany przez architektów: Luigi Figini i Gino Pollini oraz Nostra Signora della Misericordia (Baranzate), Angelo Mangiarotti i Bruno Morassutti. Bryły świątyni są wyważone, prawie szorstkie w swej prostocie. Przestronna aula kościoła w Baggio jest trzynawowa z kolumnami z żelbetonu. Ogromny otwór w prezbiterium pozwala na swobodne wejście światła $z$ jednoczesnym podkreśleniem ołtarza i tabernakulum jako najistotniejszych miejsc w świątyni ${ }^{23}$. Świątynia w Baranzate jest symbolem ogromnej zmiany w tradycyjnym postrzeganiu bryły kościoła. W całości wykonana z półprzezroczystego szkła, dyskusyjna budowla sakralna na północnym przedmieściu Mediolanu jest nazwana kościołem ze szkła.

\section{PIĘKNO UKRYTE W MURACH KATEDRY}

Zamiłowanie arcybiskupa Montiniego oraz niezwykła wrażliwość na piękno sztuki powraca wielokrotnie w homiliach i przemówieniach. 26 kwietnia 1959 r., na zakończenie prac restauracyjnych w Cremie, kierując słowo do zgromadzonych w katedrze zwraca uwagę na mistyczną atmosferę ukrytą w majestatycznych i potężnych murach świątyni. „Potrzebujemy tego -stwierdza- potrzebujemy nastroić nasze dusze do miejsca gdzie się znajdujemy. Prawie wejść w dialog z tymi murami" ${ }^{24}$. Intelektualista Montini szuka przyczyny, która od wieków przyciąga wiernych do kontemplacji Boga w romańsko-lombardzkich murach katedry w Cremie. Jako pierwszą wymienia wielkość. „Dla nas współczesnych, którzy spę-

il medesimo tempio senza mai averlo osservato nella sua struttura unitaria e nel cumulo delle sue bellezze storiche ed artistiche; e perciò, affinchè locchio del fedele sappia scoprire la gloria di Dio nella sua Chiesa, ogni particolare del tempio deve essere tenuto in ordine e mostrato a spirituale conforto". G.M. Montini, Leducazione liturgica, s. 1943-1944.

${ }^{23}$ Por. C. De Seta, Architetture della fede in Italia. Dalle origini ai nostri giorni, Milano 2003, s. 169-173.

${ }^{24}$ „Ed abbiamo bisogno di ciò; di sintonizzare le nostre anime al luogo, dove siamo; e quasi a dialogo con queste mura". G.M. Montini, Il segreto della cattedrale, w: Discorsi e scritti milanesi (1954-1963), X. Toscani (red.), vol. II, Brescia-Roma 1997, s. 2784. 
dzamy życie w ciasnych pudełkach naszych ekonomicznych mieszkań, te imponujące i dostojne głębie poszerzają serce; ale wiele innych konstrukcji jest wysokich i przestronnych i nie przemawiają do naszej duszy jak ta" 25 . Jako następne przyczyny wymienia wiek i historię. „Daje nam [wiek] dreszcz emocji i prawie czcigodny lęk; ale szybko uświadamiamy sobie, że mamy do czynienia z materialnym bezruchem; coś innego nas drażni” ${ }^{26}$. Tym czymś innym, jest piękno ukryte w murach. Monument „to nie jest jedynie dokument przeszłości; jest tu coś odmiennego, coś wiecznego; jest to nie tylko przesłanie o rzeczach ubiegłych, tu jest wieczna pieśń, teraźniejsza ekspresja; tu jest piękno! tu jest sztuka! [...] ona nas upaja”27. Nie zapominając o szerokim spektrum symbolicznym katedry, Montini zestawia piękno z wiarą. „Przede wszystkim, jest tu znaczenie religijne, i jest ono bez wątpienia tym najistotniejszym" ${ }^{28}$.

\section{ARTYSTA W OAZIE SPOKOJU}

Sztuka to jednak nie tylko rzeczy materialne, to przede wszystkim ludzie ją tworzący. 29 listopada 1959 r. kardynał Montimi podczas wizyty w domu spokojnej starości dla artystów „Giuseppe Verdi”, zwrócił się do emerytowanych twórców kultury. Podczas przemówienia, zwrócił uwagę, iż każdy z nich przyniósł ze sobą do - jak się wyraził - tej oazy spokoju sławę i doświadczenie życiowe. Miejsce, w którym się znajdują, jest tak różne od świata, który poznali. Montini z ogromnym wyczuciem

25 „[...] per noi moderni, che passiamo la vita nelle scatole anguste dei nostri appartamenti economici, queste profondità sontuose e solenni ci allargano cuore; ma altri edifici son alti e spaziosi, e non ci parlano allo spirito come questo". G.M. Montini, Il segreto, s. 2784.

${ }^{26}$, „...] ci dà un brivido di emozione e quasi di riverenziale timore; ma ci accorgiamo subito che si tratta d'un immobilità materiale; qualche altra cosa ci tormenta”. G.M. Montini, Il segreto, s. 2784.

27, „...] qui non è solo un documento di storia passata; vi è qualche cosa di diverso e di eterno; vi è non solo un messaggio narrativo di cose trascorse, vi è un canto perenne, un'espressione presente; vi è una bellezza! vi è l'arte! Oh, si! questa vi è, e ci inebbria [...]”. G.M. Montini, Il segreto, s. 2785.

${ }^{28}, \mathrm{Vi}$ è soprattutto, un significato religioso, ed è certamente quello più importante", tamże. 
zwraca uwagę, iż w domu Verdiego, odnajdą spokój, odpoczynek i możliwość kontemplacji, która być może była niemożliwa w świecie pełnych chaosu.

Artysta wycofany z życia publicznego może szukać w sobie samym i odnaleźć ducha tego, co nieraz chciał uchwycić. Nie wszystko jest skończone. [...] Bóg jest pięknem: artysta nawet jeśli nie ma już w rękach narzędzi lub głosu może duchowo szukać Boga, odpowiedzieć na Jego głos który nawołuje ${ }^{29}$.

\section{EKSPERYMENT WOLNOŚCI W EKSPRESJI TWÓRCZEJ}

Na kilka miesięcy przed wyborem na Stolicę Piotrową, kardynał Montini uczestnicząc w kongresie $\mathrm{UCAI}^{30}$, zwraca się do zgromadzonych artystów. W przemówieniu z 2 lutego 1963 r., wyraźnie wybrzmiewają koncepcje, które zostaną powtórzone w słynnym przemówieniu skierowanym do artystów w Kaplicy Sykstyńskiej 7 maja 1964 r. ${ }^{31}$ Kardynał Montini, zwraca uwagę na problem sztuki współczesnej, która dla odbiorców wydaje się wieżą Babel ${ }^{32}$.

Wydaje się, że artyści rezygnują z przedstawiania dzieł zrozumiałych, a krytycy używają żargonu, który domaga się wtajemniczenia, aby zrozumieć w jego znaczenie. My - odbiorcy - z ogromnym wysiłkiem próbujemy cokolwiek zrozumieć; wierzyliśmy, że królestwo sztuki było

29 "Lartista in ritiro può cercare dentro di sè e rivivere lo spirito di ciò che tante volte ha voluto afferrare. Non tutto è finito. [...] Dio è bellezza: e l’artista anche se non ha più strumenti nelle mani o voce su le labbra può con l'anima cercare Dio, rispondere alla Sua voce che chiama ed incalza". G.M. Montini, Dio è bellezza, w: Discorsi e scritti milanesi (1954-1963), X. Toscani (red.), vol. II, Brescia-Roma 1997, s. 3180.

${ }^{30}$ Unione Cattolica Artisti Italiani

31 Zob. Paolo VI su l'arte e agli artisti. Discorsi, messaggi e scritti (1963-1978), P. V. Begni Redona (red.), Brescia-Roma 2000, s. 23-31; tekst w języku polskim: Paweł VI, Przemówienie skierowane do artystów 7 maja 1964, „Znak” 16 (1964) 12, s. $1425-1426$.

32 Por. G.M. Montini, Lartista è il ponte, w: Discorsi e scritti milanesi (1954-1963), X. Toscani (red.), vol. III, Brescia-Roma 1998, s. 5557. 
błogością a teraz jest cierpieniem i bezładem. [...] język sztuki [...] jest abstrakcyjny, irracjonalny, hermetyczny i bez sensu ${ }^{33}$.

Chaos, do którego nawiązuje Montini, jest owocem sztuki końca XIX i początku XX wieku. Artysta odbiega od przyjętych przez Kościół kanonów piękna $\mathrm{w}$ sposobie przedstawiania rzeczywistości. Ostry ton przemówienia, wynika z obawy, iż postępujące oddalanie się od siebie świata sztuki i świata dogmatów, doprowadzi, czy też już doprowadziło, do niemożliwości znalezienia wspólnego języka zdolnego wyrazić misterium. Przemówienie do artystów jest próbą znalezienia dialogu, między Kościołem a trendami sztuki współczesnej. Jest pierwszym krokiem ku odnowie sztuki sakralnej, pozostającej w sferze imitacji stylów poprzednich epok, które w żaden sposób nie odpowiadają realnym potrzebom wiernych. Montini, który poszukuje od wczesnych lat kapłaństwa dialogu między nurtami sztuki współczesnej i sztuką sakralną, dostrzega potrzebę wyjścia naprzeciw środowisku kultury.

Mówię z mojego punktu widzenia, jako kapłana, człowieka Kościoła, który patrzy na artystów z wielką nadzieją. Potrzebujemy was. My, ludzie religii mamy cały niewidoczny, nieziemski, ultraczuły świat, który należy uczynić przystępnym dla człowieka, któremu nie można przekazać mistycznego skarbu, jak tylko poprzez «sakrament», to znaczy sakralny i delikatny znak sztuki [...] poprzez pewną «materializację» rzeczy duchowych. I to jest to co czyni artysta. To jest jego magia, jego misja ${ }^{34}$.

33 „Gli artisti sembrano rinunciare a presentare opere intelligibili, e i critici hanno un gergo loro che esige un'iniziazione per penetrare il significato. Noi - pubblico - facciamo sforzi commoventi per afferrare qualche cosa; credevamo che il regno dell'arte fosse beatitudie, ed è ora sofferenza e confusione. [...] linguaggio artistico, invalso nella moda del tempo, è quello d'un astrattismo irrazionale ed ermetico, che non ha senso [...]”. G.M. Montini, Lartista è il ponte, s. 5557-5558.

34 „Dico dal mio punto di vista di Sacerdote, di uomo di Chiesa, che guarda agli artisti sempre con grande speranza. Ne abbiamo bisogno. Noi uomini della religione abbiamo tutto un mondo invisibile, soprannaturale, ultrasensibile da rendere accessibile all'uomo, al quale non può comunicarsi il nostro misterioso tesoro, se non mediante il «sacramento», cioè il segno sacro e sensibile dell'arte, [...] cioè mediante una qualche «materializzazione» delle cose spirituali, ed è ciò che compie l'artista. E’ la sua magia, è la sua missione”. G.M. Montini, Lartista è il ponte, s. 5558. 
Dla Montiniego artysta jest mediatorem między niewysłowionym i mistycznym Słowem Bożym a człowiekiem współczesnym, któremu należy przybliżyć prawdy wiary.

Artysta jest wehikułem, pośrednikiem, mostem między naszym światem duchowym i religijnym a społeczeństwem i doświadczeniem innych, dusz do których idziemy z przesłaniem. [...] Realizuje on prawie posługę para-kapłańską, obok naszej: my tą, tajemnic boskich, on tą - współpracy człowieka, który wyraża współczesne i zrozumiałe owe tajemnice ${ }^{35}$.

Innym, złożonym problemem jest to, czy artysta tworzący sztukę sakralną powinien być wierzący. Dalsza wypowiedź kardynała nie pozostawia złudzeń. Artysta jest człowiekiem wiary, a dzieła, które tworzy, są owocem medytacji i zjednoczenia $\mathrm{z}$ Bogiem. Tylko w ten sposób jego wytwory mogą wyrażać misterium wiary i być przystępne i zrozumiałe dla wiernych.

Artyści katoliccy, mamy was blisko, przez co zachęcamy was jak tylko możecie do zrozumienia nas, do picia $\mathrm{z}$ naszego niewidzialnego i pozaziemskiego źródła, z naszego duchowego doświadczenia. Po czym zaufamy wam i powierzymy, to co mamy najcenniejsze: nasze kościoły, wspólnoty, nasze ceremonie, dlatego, że jesteście kompetentnymi do ich animacji z cnotą, która jest wam właściwa: cnotą ekspresji, intuicyjnej komunikacji artystycznego $\mathrm{czaru}^{36}$.

Milowym krokiem w przemówieniu Montiniego, jest zaproponowanie „eksperymentu” dania pełnej wolności artystom w ich kreacjach.

35 „Lartista è il veicolo, è il tramite, è il ponte fra il nostro mondo religioso e spirituale e la società e l'esperienza degli altri e le anime con cui veniamo a colloquio [...] compie quasi un ministero parasacerdotale accanto al nostro: noi quello dei misteri i Dio, e lui quello della collaborazione umana, che descrive presenti e accessibili questi misteri”. G.M. Montini, L'artista è il ponte, s. 5559.

36 „Artisti cattolici vi teniamo vicini, e perciò vi invitiamo quanto potete a capirci, a bere alla nosta sorgente invisibile e soprannaturale e alla nostra esperienza religiosa, e poi ci fidiamo di voi e vi diamo ciò che abbiamo di più prezioso: le nostre chiese, le nostre adunanze, le nostre cerimonie, perchè voi siate capaci appunto di animarle con vitrù che è proprio vostra: della espressione, della comunicazione intuitiva, del fascino artistico". G.M. Montini, Lartista è il ponte, s. 5559. 
Przywołując dzieło świętego Karola Boromeusza, zauważa on, iż do tej pory Kościół narzucał pewne reguły, swoją wizję sztuki nie pozostawiając do końca pełnej, niczym nieograniczonej ekspresji artystycznej.

Zostało wam powiedziane i to nie tylko w Mediolanie: róbcie tak jak uważacie! Nie domagamy się już od was, ani podążania za daną tradycją, ani za danym stylem, ani za czymś innym. Nie będziecie zobowiązani do uchwycenia danych wymiarów, ani danych form konwencjonalnych ${ }^{37}$.

Nieograniczona wolność działania na polu sztuki sakralnej jest kamieniem milowym w nauczaniu Kościoła. Warto wspomnieć, przemówienie papieża Piusa XI z 27 października 1932 r., które wygłosił podczas inauguracji Pinakoteki Watykańskiej. Odnosząc się do współczesnej sztuki sakralnej, którą nazwał brzydką i karykaturalną, wyraźnie zaznaczył, ŻE:

już to wielokrotnie mówiliśmy ludziom sztuki i pasterzom: Naszą nadzieją, Naszym gorliwym głosem, Naszym pragnieniem jest jedynie, aby [sztuka sakralna] była posłuszna prawu kanonicznemu jasno i legalnie sformułowanemu również w Kodeksie Prawa Kanonicznego, to znaczy, aby ta [sztuka] nie była przyjmowana do Naszych kościołów i co więcej, aby nie była powoływana do ich konstruowania, przekształcania, dekorowania, przy jednoczesnym otwarciu wszystkich drzwi i przyjęciu każdych dobrych, postępowych i czcigodnych tradycji, które w ciągu wieków chrześcijaństwa w dużej różnorodności środowiska, warunków społecznych i etycznych, dały dowód niewyczerpanej zdolności do inspiracji nowych i pięknych form, tyle razy ile zostały one badane, studiowane i pielęgnowane w podwójnym świetle geniuszu i wiary ${ }^{38}$.

37 „Vi è stato detto, e non solo a Milano: fate quello che volete! non vi chiederemo più nè di seguire una data tradizione, nè un dato stile, nè un altro; nè sarete obbligati a tenere date misure, nè date forme convenzionali [...]". G.M. Montini, Lartista è il ponte, s. 5559.

38 „Lo abbiamo del resto già più volte espresso con uomini d’arte e con sacri Pastori: la Nostra speranza, il Nostro ardente voto, la Nostra volontà può essere soltanto che sia ubbidita la legge canonica, chiaramente formulata e sancita anche nel Codice di Diritto Canonico, e cioè: che tale arte non sia ammessa nelle Nostre chiese e molto più che non sia chiamata a costruirle, a trasformarle, a decorarle, pur spalancando tutte le porte e dando il più schietto benvenuto ad ogni buono e progressivo sviluppo delle buone e venerande tradizioni, che in tanti secoli di vita cristiana, in tanta diversità di ambienti e di condizioni sociali ed etniche, hanno dato tanta prova di inesauribile capacità 
Montini, poszukując mostu łączącego artystę i wspólnotę Kościoła i dając ową wolność w tworzeniu, zaznacza, że sztuka ma być służebna, funkcjonalna i zrozumiała. „Bądźcie naprawdę w łączności i zgodności z kultem i duchowością chrześcijańską: i później róbcie co uważacie!"39. Podobnie jak w Liście Duszpasterskim na Wielki Post (1958) zwraca uwagę na przywiązanie do liturgii; „niech będzie to zaszczepienie między waszym językiem a moim, między moją liturgią a waszą ekspresją, między tym, co ja muszę oznajmiać, a tym, co wy, mistrzowie kolorów, cyrkli, dźwięków malujecie, konstruujecie lub wyrażacie"40. Na zakończenie przemówienia kardynał zwraca uwagę na potrzebę jedności i wspólnoty między artystami wierzącymi. Choć każdy z nich jest indywidualistą, wolnym od reguł, co sam podkreślił, artysta potrzebuje wymiany myśli i koncepcji. Tylko w ten sposób może narodzić się nowy styl, który będzie w stanie wyrazić ducha współczesnego społeczeństwa.

[...] sztuka, która tworzy epokę, rodzi się ze wspólnoty, którą artyści mogą tworzyć nie tylko z ludźmi ich czasu, ale między sobą. Poznają się wzajemnie i w ten sposób rodzi się styl ${ }^{41}$.

\section{BIBLIOGRAFIA}

Adornato G., Giovanni Battista Montini. Religione e lavoro nella Milano degli anni ,50, Brescia 1988.

Crippa M. A., Lesperimento pastorale del card. Giovanni Montini nella diocesi ambrosiana, w: La diocesi di Milano e le nuove chiese 1954-2014. Atti del Convegno, 4 novembre 2014, L. Lazzaroni (red.), Milano 2016, s. 61-96.

di ispirare nuove e belle forme, quante volte vennero interrogate o studiate e coltivate al duplice lume del genio e della fede". Pio XI, La parola del Santo Padre sullarte sacra, «Arte Sacra» 3-4 (1932), s. 293.

${ }^{39}$ "Siate veramente in comunicazione ed in sintonia con il culto e con la spiritualità cristiana; e dopo fate quello che volete!". G.M. Montini, Lartista è il ponte, s. 5561.

${ }^{40},[\ldots]$ ci sia questo innesto fra il vostro linguaggio e il mio, fra la mia liturgia e la vostra espressione, fra quello che io devo comunicare e quello che voi, padroni dei colori, dei compassi, dei suoni dipingete, o costruite, o esprimete". G.M. Montini, L'artista è il ponte, s. 5561.

${ }^{41},[\ldots]$ l'arte che fa epoca, nasce appunto da una società, che gli artisti possono avere non soltanto con gli uomini del loro tempo, ma fra di loro. Si leggono gli uni con gli altri, e nasce cosi lo stile". G.M. Montini, L’artista è il ponte, s. 5562. 
Dall'Asta A., Arte cristiana e cultura contemporanea. Tra declino e speranza di riscatto, «La Civiltà Cattolica», 4011-4012 (2017) 3, s. 305-315.

De Carli C., Le nuove chiese, w: Montini. Arcivescoco di Milano, L. Bressan, A. Maffeis (red.), Brescia 2016, s. 295-329.

De Caro E., L'estetica e il progetto di nuova evangelizzazione degli artisti, «Itinera» 11 (2016), s. 201-213.

De Seta C., Architetture della fede in Italia. Dalle origini ai nostri giorni, Milano 2003.

Montini G.B., E' venuta l'ora di unarte cattolica nuova, w: Discorsi e scritti milanesi (1954-1963), X. Toscani (red.), vol. I, Brescia-Roma 1997, s. 563-565.

Montini G.M., Dio è bellezza, w: Discorsi e scritti milanesi (1954-1963), X. Toscani (red.), vol. II, Brescia-Roma 1997, s. 3180.

Montini G.M., Il miracolo delle vetrate, w: Discorsi e scritti milanesi (1954-1963), X. Toscani (red.), vol. I, Brescia-Roma 1997, s. 1701.

Montini G.M., Il segreto della cattedrale, w: Discorsi e scritti milanesi (1954-1963), X. Toscani (red.), vol. II, Brescia-Roma 1997, s. 2782-2793.

Montini G.M., Lartista è il ponte, w: Discorsi e scritti milanesi (1954-1963), X. Toscani (red.), vol. III, Brescia-Roma 1998, s. 5556-5564.

Montini G.M., Leducazione liturgica, Lettera pastorale all'arcidiocesi per la Quaresima, w: Discorsi e scritti milanesi (1954-1963), X. Toscani (red.), vol. II, Brescia-Roma 1997, s. 1931-1954.

Paolo VI su l'arte e agli artisti. Discorsi, messaggi e scritti (1963-1978), Begni Redona P. V. (red.), Brescia-Roma 2000, s. 23-31.

Pappalardo G., Lo spazio sacro del Novecento: architetture religiose delle città e dei borghi di fondazione nell'Italia meridionale, «Bollettino del centro di studio per la storia dell'architettura», 42-43-44 (2005-2007) s. 141-144.

Paweł VI, Przemówienie skierowane do artystów 7 maja 1964, „Znak” 16 (1964) 12, s. $1425-1426$.

Pio XI, La parola del Santo Padre sull'arte sacra, "Arte Sacra» 3-4 (1932), s. 293-296.

Pio XII, Mediator Dei, AAS 39 (1947), s. 521-595.

Potestà G. L., Lepiscopato di G. M. Montini a Milano (1955-1963), w: Chiese italiane e Concilio. Esperienze pastorali nella chiesa italiana tra Pio XII e Paolo VI, G. Alberigo (red.), Genova 1988, s. 107-128.

Salamone F., Perenne rivelazione dell'arte cristiana. Per una teologia dellarte in Paolo VI, Palermo 2013. 